\title{
М.А. Андрейчин
}

\section{НЕБЕЗПЕЧНА ДИНАМІКА ІНФЕКЦІЙНОЇ ЗАХВОРЮВАНОСТІ В УКРАÏHI}

Тернопільський державний медичний університет ім. І.Я. Горбачевського, Всеукраїнська асоціація інфекціоністів

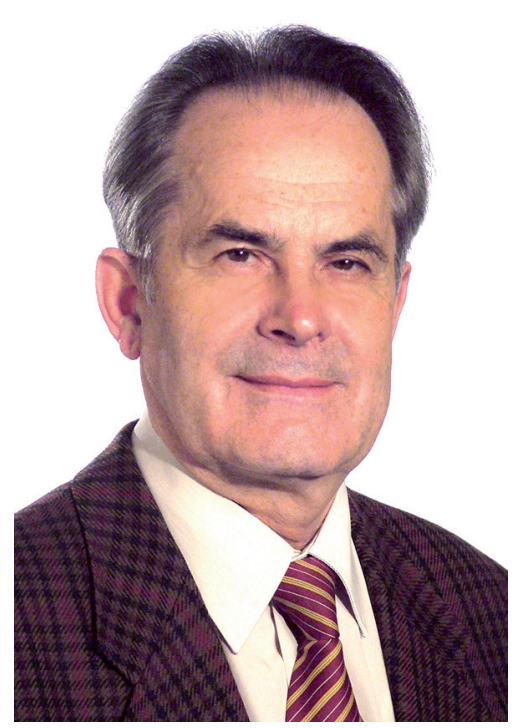

Мета роботи - проаналізувати інфрекційну захворюваність в Україні за останні роки і обґрунтувати причини епідемічних ускладнень.

Вказано на основні загрози активізації інфрекційних хвороб в Україні та причини несприятливої епідемічної ситуації, що склалася на сьогодні. Наведено динаміку захворюваності та смертності від цих хвороб за період з 2010 по 2011 рр. Перелічені хвороби, які супроводжувалися у 2016 р. приростом захворюваності в абсолютних числах і з розрахунку на 100 тис. населення. Зроблено акцент на почастішання епідемічних спалахів. Обірунтована важливість проблеми внутрішньолікарняних інфрекцій і необхідність їх повнішої реєстрації. Показана доцільність внесення змін у список орфранних інфекцій, затверджений МОЗ України.

Висновок. В Україні зростає інфрекційна захворюваність на ряд нозологічних фрорм і почастішали епідемічні ускладнення, що потребує більших профрілактичних, протиепідемічних і клінічних зусиль. Першочергові заходи слід спрямувати на усунення (послаблення) названих причин такого стану.
Ключові слова: інфекційна захворюваність, смертність, приріст захворюваності, епідемічні спалахи, внутрішньолікарняні інфекції, орфанні інфекції.

Поглиблений аналіз етіологічної структури та динаміки інфекційної захворюваності показує, що епідемічна ситуація у світі та Україні продовжує ускладнюватися. На зміну пандеміям натуральної віспи та чуми, які давно відійшли в минуле, прийшли пандемії ВІЛ-інфекції/ СНІДу та парентеральних вірусних гепатитів. Досі некерованою залишається велика група гострих респіраторних захворювань, серед яких найбільшу соціальноекономічну та медичну вагомість зберігає грип. Чітко окреслилась актуальність великої групи герпетичних інфекцій. За останні 30 років завдяки науково-технічному прогресу відкрито майже 60 збудників інорекційних хвороб, розповсюдження яких по земній кулі потребує широкомасштабних досліджень. Відповідно все більшої ваги набуває проблема емерджентних і орфанних інфекцій.

Мета роботи - проаналізувати інфеекційну захворюваність в Україні за останні роки і обґрунтувати причини ії приросту та епідемічних ускладнень.

До нових загроз інфрекційних хвороб в Україні необхідно віднести: глобальне поширення інсекцій; повернення старих і появу нових інфекцій; реєстрацію екзотичних інфекцій; активізацію наявних ендемічних осередків інфекцій; ризик фрормування нових природних осередків (малярії, лейшманіозу та ін.) [1-3].

Згідно з даними ВОО3, у світі показник смертності від інфекційних хвороб на другому місці після кардіоваскулярних причин. ВООЗ прогнозує до 2030 р. зростання смертності від серцево-судинних хвороб і запалень легень та зменшення - від інфекційних хвороб. Проте запалення легень переважно інфекційної природи, тому рівень інфекційної захворюваності та смертності навряд чи суттєво знизиться.

Дуже показовою $€$ динаміка захворюваності та смертності від інфекційних хвороб в Україні, за даними Міністерства охорони здоров'я. У 2010-2011 рр. рівень 
захворюваності опустився нижче рівня смертності. Оскільки якість реанімаційної допомоги хворим на тяжкі інфекційні захворювання має схильність до поліпшення у зв'язку з науково-технічним процесом, то можна стверджувати, що в умовах зниження рівня інфекційної захворюваності смертність також повинна знижуватись, в усякому разі крива смертності мала би бути нижче рівня захворюваності, як це спостерігалось до зазначених років. Тому деяке зниження рівня інфекційної захворюваності $€$ підставою пояснити погіршенням їх офріційної реєстрації. Останні три роки в Україні не реєструється іноекційна захворюваність в анексованому Росією Криму і на значній території Донецької та Луганської областей, включно з їх обласними центрами. А саме на цих територіях у попередні роки захворюваність на низку інфекцій була вища, ніж, наприклад, в західному регіоні країни.

Попри наведені міркування, сумарна інфекційна захворюваність (без врахування ВІЛ-інфекції), за даними ДЗ «Український центр контролю і моніторингу захворювань МОЗ», зросла на 17,82 \% (табл. 1), головним чином за рахунок грипу та ГРЗ. Приріст дали: сальмонельозна інфекція, за винятком черевного тифу і паратисрів А, В, С (на 7,08 \%), шигельоз Зонне (12,04 \%), харчова токсикоінфекція (5,50 \%), лептоспіроз (7,31 \%), кашлюк (29,10\%), вірусний менінгіт (8,99 \%), гепатит А $(21,97 \%)$, гострий гепатит В $(8,43 \%)$, інфекційний мононуклеоз (12,51 \%), інші трематодози (1,10\%), в тому числі опісторхоз (1,94\%), аскаридоз (8,66 \%), гострі інфекції верхніх дихальних шляхів (17,99 \%), грип (у 3,77 разу), пневмококовий менінгіт (89,47 \%), інші бактерійні менінгіти (4,15\%). А ще захворюваність на низку інфекцій показала зростання на один або декілька випадків (диортерія, паракашлюк, рикетсіози, кліщовий вірусний енцефраліт, геморагічна гарячка з нирковим синдромом, носії збудників черевного тифу і паратифрів).

Водночас відбулося значне зниження захворюваності на шигельоз Флекснера, єрсиніоз, скарлатину, менінгококову інфекцію, хворобу Лайма, вірусні гарячки, краснуху, гострий гепатит С, хронічний вірусний гепатит, у тому числі хронічний гепатит $\mathrm{B}$, епідемічний паротит, малярію, гіменолепідоз, трихуроз, менінгіт, спричинений H. influenzae.

Безперечно, зростання захворюваності на низку інфекцій в 2016 р. може бути зумовлено кращою їх діагностикою, а також періодичністю багаторічного епідемічного процесу. Однак на прикладі зниження захворюваності на хворобу Лайма з 7,96 до 6, 45 випадків на 100 тис. населення, що склало 19,19\%, можна висловити здивування. Адже в деяких областях, в яких проведено значну санітарно-освітню роботу і відносно краще налагоджено специфрічну лабораторну діагнос- тику цієї інфекції, різко почастішало звертання населення у зв'язку з укусами кліщів. Специфічне обстеження хворих з хронічною запально-дистрофрічною патологією шкіри, суглобів, серця, периферичної та центральної нервової системи дає змогу значно частіше діагностувати цю небезпечну інсекцію. Так, тільки у Тернопільській області у 2016 р. порівняно з 2015 р. частота діагностики Лайм-бореліозу збільшилася на $27,8 \%$.

Як відомо, широке планове щеплення населення, особливо дітей, привело до зниження інфекційної захворюваності у світі та Україні. Яскравим прикладом може бути багаторічне планове щеплення від поліомієліту. Якщо у 1988 р. поліовірус був розповсюджений в 125 країнах, то зараз він реєструється лише в 3-х - у Пакистані, Афрганістані, Нігерії, які залишаються ендемічними щодо поліомієліту. Україна була віднесена до країн Європейського регіону, вільного від поліомієліту. Однак на тлі стрімкого погіршення вакцинопрофілактики в Україні знов почали реєструватися випадки вакциноасоційованого паралітичного поліомієліту (2 у 2015 р.). Водночас зросла кількість випадків гострого в'ялого паралічу, що співпадало в часі 3 прийомом оральної поліомієлітної вакцини [4]. Критична ситуація, що склалася в останні роки в Україні з вакцинопрофрілактикою, стосується також інших інфекцій, керованих засобами вакцинопрофілактики. В останні роки показник захворюваності на кір підвищився до 0,24 на 100 тис. населення (табл. 1). А ще зовсім недавно ВООЗ прогнозувала ерадикацію кору на Європейському континенті.

Дуже складна епідемічна ситуація щодо ВІЛ-інфекції. За оперативними даними дУ «Центр громадського здоров'я Міністерства охорони здоров'я України»:

- за період 1987-2016 рр. в країні офріційно зареєстровано 297424 випадки ВІЛ-інфекції серед громадян України, у тому числі 92897 випадків СНІД і 41710 випадків смерті від захворювань, зумовлених СНІД;

- станом на 01.01.2017 р. під медичним наглядом перебуває майже 133 тис. ВІЛ-інфрікованих осіб, з них кожен третій має діагноз СНІД [6].

У 2016 р. в Україні спостерігалося збільшення кількості зареєстрованих ВІЛ-інфрікованих осіб - 17066 проти 15869 у 2015 р., темп приросту становив + 7,5 \%, показник захворюваності досяг 40,0 на 100 тис. населення проти 37,0 на 100 тис. у попередньому році. Значні темпи приросту захворюваності на ВІЛ-інфекцію зареєстровано у Донецькій, Закарпатській, Запорізькій, Київській, Луганській, Миколаївській, Тернопільській, Харківській, Херсонській областях та м. Києві. Аналіз цих даних свідчить про те, що створена свого часу сітка автономних обласних і міських СНІД-центрів не виконала покладених на них сподівань. 
ПЕРЕДОВА СТАТТЯ

Таблиця 1

Інфекційна захворюваність населення в Україні (за даними дз «УЦКМЗ МОЗ»)

\begin{tabular}{|c|c|c|c|c|c|}
\hline \multirow[b]{2}{*}{ Найменування захворювання } & \multicolumn{2}{|c|}{2015 рік } & \multicolumn{2}{|c|}{2016 рік } & \multirow[b]{2}{*}{$\begin{array}{c}\text { Зниження, } \\
\text { ріст (\%) }\end{array}$} \\
\hline & $\begin{array}{l}\text { абс. } \\
\text { число }\end{array}$ & \begin{tabular}{|l|} 
на 100 тис. \\
населення
\end{tabular} & $\begin{array}{l}\text { абс. } \\
\text { число }\end{array}$ & $\begin{array}{l}\text { на } 100 \text { тис. } \\
\text { населення }\end{array}$ & \\
\hline Сальмонельозні інфекції (крім черевного тифу і паратифрів) & 8350 & 19,46 & 8941 & 20,91 & 7,08 \\
\hline Шигельоз, усього & 934 & 2,18 & 913 & 2,14 & $-2,25$ \\
\hline у т. ч.: спричинений шигелами Флекснера & 360 & 0,84 & 335 & 0,78 & $-6,94$ \\
\hline спричинений шигелами Зонне & 357 & 0,83 & 400 & 0,94 & 12,04 \\
\hline $\begin{array}{l}\text { Ентерити, коліти, гастроентерити, харчові токсикоінсрекції, } \\
\text { спричинені іншими встановленими збудниками }\end{array}$ & 52889 & 123,27 & 52221 & 122,13 & $-1,26$ \\
\hline у т. ч. кампілобактеріальний ентерит & 114 & 0,27 & 109 & 0,25 & $-4,39$ \\
\hline ентерити, спричинені єрсинією ентероколітікою & 128 & 0,30 & 107 & 0,25 & $-16,41$ \\
\hline ротавірусний ентерит & 12388 & 28,87 & 12119 & 28,34 & $-2,17$ \\
\hline $\begin{array}{l}\text { Гострі кишкові інфекції, спричинені невстановленими } \\
\text { збудниками, та неточно визначені харчові токсикоінорекції }\end{array}$ & 41891 & 97,64 & 44197 & 103,36 & 5,50 \\
\hline Лептоспіроз & 301 & 0,70 & 323 & 0,76 & 7,31 \\
\hline Кашлюк & 2426 & 5,65 & 3132 & 7,32 & 29,10 \\
\hline Скарлатина & 8035 & 18,73 & 6677 & 15,62 & $-16,90$ \\
\hline Менінгококова інфекція & 335 & 0,78 & 270 & 0,63 & $-19,40$ \\
\hline Хвороба Лайма & 3413 & 7,96 & 2758 & 6,45 & $-19,19$ \\
\hline Вірусний менінгіт & 445 & 1,04 & 485 & 1,13 & 8,99 \\
\hline Вітряна віспа & 127476 & 297,12 & 127058 & 297,14 & $-0,33$ \\
\hline Kip & 105 & 0,24 & 102 & 0,24 & $-2,86$ \\
\hline Краснуха & 247 & 0,58 & 150 & 0,35 & $-39,27$ \\
\hline Вірусний гепатит & 12409 & 28,92 & 12688 & 29,67 & 2,25 \\
\hline у т. ч. гострий гепатит A & 2481 & 5,78 & 3026 & 7,08 & 21,97 \\
\hline гострий гепатит В & 1353 & 3,15 & 1467 & 3,43 & 8,43 \\
\hline гострий гепатит C & 589 & 1,37 & 563 & 1,32 & $-4,41$ \\
\hline хронічний вірусний гепатит & 7823 & 18,23 & 7459 & 17,44 & $-4,65$ \\
\hline у т. ч. хронічний гепатит В & 1756 & 4,09 & 1535 & 3,59 & $-12,59$ \\
\hline хронічний гепатит C & 5985 & 13,95 & 5854 & 13,69 & $-2,19$ \\
\hline Епідемічний паротит & 461 & 1,07 & 439 & 1,03 & $-4,77$ \\
\hline Інфрекційний мононуклеоз & 5069 & 11,81 & 5703 & 13,34 & 12,51 \\
\hline Малярія & 51 & 0,12 & 43 & 0,10 & $-15,69$ \\
\hline Інші трематодози & 365 & 0,85 & 369 & 0,86 & 1,10 \\
\hline у т. ч. опісторхоз & 360 & 0,84 & 367 & 0,86 & 1,94 \\
\hline Гіменолепідоз & 128 & 0,30 & 83 & 0,19 & $-35,16$ \\
\hline Аскаридоз & 38555 & 89,86 & 41895 & 97,98 & 8,66 \\
\hline Трихуроз & 1805 & 4,21 & 1472 & 3,44 & $-18,45$ \\
\hline Ентеробіоз & 58984 & 137,48 & 58278 & 136,29 & $-1,20$ \\
\hline $\begin{array}{l}\text { Гострі інсрекції верхніх дихальних шляхів множинних або } \\
\text { неуточнених локалізацій }\end{array}$ & 6535862 & 15233,87 & 7711915 & 18035,49 & 17,99 \\
\hline Грип & 19420 & 45,26 & 73243 & 171,29 & 3,77 разу \\
\hline Пневмококовий менінгіт & 38 & 0,09 & 72 & 0,17 & 89,47 \\
\hline Інші бактерійні менінгіти & 289 & 0,67 & 301 & 0,70 & 4,15 \\
\hline Носії збудників нетоксигенних штамів дифртерії & 63 & 0,15 & 45 & 0,11 & $-28,57$ \\
\hline Всього & 6920398 & 16130,15 & 8153816 & 19068,94 & 17,82 \\
\hline Всього (без носіїв) & 6920334 & 16130,01 & 8153769 & 19068,83 & 17,82 \\
\hline Всього (без носіїв, грипу і ОР3) & 365052 & 850,87 & 368611 & 862,05 & 0,97 \\
\hline
\end{tabular}


Особливе занепокоєння серед медичних працівників і громадського загалу викликають все частіші спалахи інфекційних хвороб (табл. 2). 32012 по 2016 рр. число спалахів зросло з 34 до 166. Відповідно збільшилася кількість постраждалих - 3673 до 3140 осіб, в тому числі дітей. Епідемічні спалахи були спричинені головним чином сальмонелами, шигелами, ротавірусами та вірусом гепатиту А, тобто збудниками кишкових інфекцій. У 2016 р. порівняно з 2015 р. майже у 2 рази збіль- шилася кількість спалахів, які виникли в організованих колективах (72 проти 37). Особливий резонанс у суспільстві спричинив епідспалах 2016 р. в м. Ізмаїл, селищах Броска, Матроска Одеської області, пов'язаний 3 вживанням недоброякісної питної води. Тоді постраждало 776 осіб, у т. ч. 449 дітей. Цей спалах та інші свідчать про незадовільний санітарно-гігієнічний контроль і подальше його зниження.

Таблиця 2

Динаміка епідемічних спалахів інфекційних хвороб в Україні за останні 5 років

\begin{tabular}{|c|c|c|c|c|c|c|}
\hline \multirow{2}{*}{ Рік } & \multirow{2}{*}{$\begin{array}{c}\text { Сумарне } \\
\text { число } \\
\text { спалахів }\end{array}$} & \multirow{2}{*}{$\begin{array}{c}\text { Кількість } \\
\text { постраждалих/ } \\
\text { у т. ч. дітей }\end{array}$} & \multicolumn{4}{|c|}{ Число спалахів окремих інфрекцій } \\
\cline { 4 - 7 } & сальмонельоз & шигельоз & $\begin{array}{c}\text { ротавірусна } \\
\text { інсрекція }\end{array}$ & $\begin{array}{c}\text { вірусний } \\
\text { гепатит А }\end{array}$ \\
\hline 2012 & 34 & $673 / 345$ & 18 & 6 & 6 & 2 \\
\hline 2013 & 48 & $822 / 243$ & 32 & 1 & 12 & 2 \\
\hline 2014 & 67 & $258 / 579$ & 37 & 0 & 18 & 8 \\
\hline 2015 & 101 & $1549 / 704$ & 47 & 3 & 25 & 21 \\
\hline 2016 & 166 & $3140 / 1563$ & 69 & 3 & & 2 \\
\hline
\end{tabular}

Окрему проблему становлять внутрішньолікарняні інсекції. Поки що за рік реєструється лише від 3 до 8 тис. випадків, найчастіше післяопераційні ускладнення, гнійно-септичні інсрекції новонароджених і породіль, інсрекції шкіри та підшкірної клітковини. Ця мізерня не відображає реальної картини, беручи до уваги слабку матеріальну базу лікувальних закладів. Сучасна наука стверджує, що інфікуванням охоплено 5-15 \% пацієнтів залежно від профрілю лікувального закладу. У США, де $€$ достатня кількість сучасних ізоляторів і підтримується належний протиепідемічний режим, щорічні втрати сягають аж 5 млрд. доларів!

Окрему проблему становлять орфанні (рідкісні) інфекції. Як відомо, до орфанних хвороб належать нозологічні форми, частота яких не перебільшує 5 випадків на 100 тис. населення. Згідно 3 наказом МОЗ України № 778 від 28.10.2014 р., до списку цих хвороб інфекційної етіології віднесено Лайм-бореліоз [5]. У 2015 р. офріційно зареєстрована захворюваність досягла на цей кліщовий бактеріоз 7,96 на 100 тис. населення. Однак справжній рівень захворюваності ще більший, тому що багато потерпілих не звертаються за медичною допомогою, специсрічна діагностика в повному обсязі не налагоджена. Тому на сьогодні вже достатньо підстав вивести хворобу Лайма зі списку орфанних інфекцій.

Несприятлива епідемічна ситуація в Україні загалом і в окремих регіонах зокрема має своє пояснення. До основних чинників такого зростання інфекційної захворюваності чи збереження на стабільно високих рівнях, крім вже названих недоліків планової імунопрофрілактики, належать: невпинне зниження матеріального добробуту більшості населення, криза системи охорони здоров'я і відсутність реформ, розвал санітарно-епідеміологічної служби і поки що мала ефективність нових державних структур, на які покладено завдання ліквідованої служби, відсутність реформи у медичній галузі, інтенсифрікація міграційних процесів, зростання резистентності збудників до антибіотиків і хіміотерапевтичних препаратів, екологічні проблеми, врай недостатнє фрінансування державної медицини і наукової сорери. До цих небажаних фракторів безперечно долучились воєнні дії на сході України та анексія Криму [1-3].

Тривала інфляція та соціально-політична нестабільність у державі гальмують боротьбу з інфрекційними хворобами. Однак історія медицини вже не раз довела, що економія коштів на боротьбу з інорекційними хворобами неминуче призводить до зростання захворюваності та епідемічних ускладнень, що потребує значно більших фрінансових витрат.

Таким чином, в Україні спостерігається активізація низки інфекційних хвороб та почастішали епідемічні спалахи, головним чином кишкових інфекцій. Офіційна реєстрація інсрекційних захворювань взагалі та внутрішньолікарняних інорекцій зокрема потребує значного поліпшення. Для покращення епідситуації потрібно здійснити комплекс невідкладних заходів на загальнодержавному і місцевому рівнях. 


\section{Література}

1. Епідеміологія: підручник для студ. вищих мед. навч. закладів / М.А. Андрейчин, 3.П. Василишин, Н.О. Виноград; за ред. І.П. Колеснікової. - Вінниця: Нова Книга, 2012. - 576 с.

2. Harrison Choroby zakaźne. Tom 1 / pod. red. Dennisa L. Kaspera, Anthony`ego S. Fauciego. - Lublin: Wydawnictwo Czelej. $-946 \mathrm{~s}$.

3. Андрейчин М.А. Тривожні тенденції інфекційної захворюваності в Україні / М.А. Андрейчин // Діагностика і терапія інсеекційних хвороб на різних рівнях надання медичної допомоги. Матеріали Всеукраїнської науково-практичної конференції інфекціоністів і пленуму ГО «Всеукраїнська асоціація інфекціоністів» (29-30 вересня 2016 року, м. Вінниця). - Тернопіль: ТДМУ, Укрмедкнига, 2016. - С. 3-4.

4. Задорожна В.І. Поліомієліт: нові виклики на шляху до ерадикації / В.І. Задорожна, О.М. Циганчук // Інфекційні хвороби. - 2016. - № 4 (86). - C. 5-12.

5. Міністерство охорони здоров'я. Наказ № 778 від 27.10.2014 p. Про затвердження переліку рідкісних (орфанних) захворювань.

6. Інформація про епідемічну ситуацію з ВІЛ-інфекції в Україні станом на 01.01.2017р. [Електронний ресурс]. Режим доступу: https://www.google.com.ua/ http://phc.org.ua/uploads/ documents/83da57/

\section{References}

1. Andreichyn, M.A., Vasylyshyn, Z.P., \& Vynohrad, N.O. Kolesnikova, I.P. (Ed.). (2012). Epidemiolohiia: pidruchnyk dlia studentiv vyshchykh medychnykh navchalnykh zakladiv [Epidemiology: textbook for the students of higher medical educational establishments]. Vinnytsia: Nova Knyha [in Ukrainian].

2. Harrison Choroby zakaźne. Tom 1 Red. by Dennis L. Kasper Anthony'ego S. Fauciego. Lublin: Wydawnictwo Czelej.

3. Andreichyn, M.A. (2016). Tryvozhni tendentsii infektsiinoi zakhvoriuvanosti v Ukraini [Anxious tendencies of infectious morbidity in Ukraine]. Diagnostics and therapy of infectious diseases on the different levels of grant of medicare: Materials of the Allukrainian scientificpractical conference of infectiologists and plenum of $P O$ «Allukrainian

\section{DANGEROUS DYNAMICS OF INFECTIOUS MORBIDITY IN UKRAINE}

M.A. Andreychyn

I. Horbachevsky State Medical University

SUMMARY. The aim of the work - to analyze the infectious morbidity in Ukraine in the last few years and to ground reasons of epidemiology complications.

It is indicated on the basic threats of infectious diseases activation in Ukraine and reasons of unfavorable epidemiology situation which was folded for today. A dynamics of morbidity and death rate from these illnesses for period from 2010 to 2011 is presented. Diseases which were accompanied in 2016 by the increase of morbidity in absolute numbers and calculating on 100 thousand population are counted. An accent is done on making more frequent of epidemic flashes. Reasonable importance of problem of inhospital infections and their necessity for more complete registration. The shown expediency of making alteration is in the list of rare infections, ratified by the Ministry of Health of Ukraine. association of infectiologists» (September, 29-30, Vinnytsia). Ternopil: Ukrmedknyha, 2016, 3-4 [in Ukrainian].

4. Zadorozhna, V.I., \& Tsyhanchuk, O.M. (2016) Poliomiielit: novi vyklyky na shliakhu do eradykatsii [Poliomyelitis: new calls on a way to erradication]. Infektsiini khvoroby - Infectious Diseases, 4 (86), 5-12 [in Ukrainian].

5. Ministry of health. Order № 778 from 27.10.2014 Pro zatverdzhennia pereliku ridkisnykh (orfannykh) zakhvoriuvan [About claim of list of rare diseases] [in Ukrainian].

6. Information about an epidemic situation from HIV-infectiuon in Ukraine by the state on 01.01.2017 [E-resource]. (2017). Retrieved from: https://www.google.com.ua/ http://phc.org.ua/uploads/ documents/83da57/

Conclusion. Infectious morbidity is growing on the row of nosology forms in Ukraine and epidemic complications became more frequent, that needs greater prophylactic, anti-epidemic and clinical efforts. Near-term measures should be directed at the removal (weakening) of the adopted reasons of such state.

Key words: infectious morbidity; death rate; increase of morbidity, epidemic flashes, in-hospital infections, orphan infections.

\section{Відомості про автора}

Андрейчин Михайло Антонович - академік НАМН України, д. мед. н., завідувач кафедри інфекційних хвороб з епідеміологією, шкірними і венеричними хворобами Тернопільського державного медичного університету ім. І.Я. Горбачевського; mandre@meta.ua

\section{Information about autor}

Andreychyn M.A. - academician of NAMS of Ukraine, medical sciences doctor, manager by the department of infectious diseases with epidemiology, by skin and venereal illnesses of the I.Ya. Horbachevsky Ternopil state medical university; mandre@meta.ua

Консрлікту інтересів немає.

Authors have no conflict of interest to declare. 